\title{
Impact of climate change on ivy (Hedera helix L.) expansion in forests of Central Poland
}

\author{
Leszek Kucharski $^{1} \bowtie$, Marek Kloss $^{2}$, Jadwiga Sienkiewicz ${ }^{3}$, Małgorzata Liszewska ${ }^{4}$, \\ Piotr Kieltyk ${ }^{2}$ \\ ${ }^{1}$ University of Lodz, Faculty of Biology and Environmental Protection, Department of Geobotany and Plant Ecology, \\ Banacha 1/3, 90-237 Łódź, Poland, e-mail: leszek.kucharski@biol.uni.lodz.pl \\ ${ }^{2}$ Cardinal Stefan Wyszyński University in Warsaw, Faculty of Biology and Environmental Sciences, Wóycickiego 1/3, \\ 01-938 Warszawa, Poland \\ ${ }^{3}$ Institute of Environmental Protection-National Research Institute, Krucza 5/11D, 00-548 Warszawa, Poland, \\ e-mail: jadwiga.sienkiewicz@ios.edu.pl \\ ${ }^{4}$ Interdisciplinary Centre of Mathematical and Computational Modelling of the University of Warsaw, Prosta 69, \\ 00-838 Warszawa, Poland
}

\begin{abstract}
The article refers to a broader context of scientific debates on the effect of climate warming on shifts in species ranges and describes the recent changes in the distribution and life strategy of Hedera helix close to its eastern limit, in light of climate changes. European ivy is an ecotone species, occurring in fringe communities, in deciduous and mixed deciduous forests in fresh and moist habitats that are occupied by oak-hornbeam and riparian alder-ash forests in Central Poland. Since the mid-20th century, the ivy, a species rarely reproducing generatively, has become an expansive plant with a growing number of sites where flowering and fruiting individuals are encountered. We studied the distribution, habitat requirements and flowering of H. helix in Central Poland in the years 2015-2017 and compared to the situation in the mid-1970s. Climate changes in terms of average air temperatures and precipitation amounts for the past four decades were also assessed. Within the study area, 474 stands of naturally growing Hedera have recently been identified. Ivy was found to reproduce generatively on 121 of those locations. There has been an almost 10-fold increase in the number of fruiting ivy specimens since the mid-1970s of the 20th century. Changes in the species life strategy can be ascribed to the increase in both average air temperatures and solar radiation intensity observed for the past decades. Both enhanced fragmentation of woodland tracts and development of forest ecotones and forest canopy openings promote the expansion of $H$. helix, while its habitat preferences remain unchanged.
\end{abstract}

\section{KeY WORDS}

expansive species, forest habitats, ecotones, climate warming 


\section{INTRODUCTION}

Climate is one of the major ecological factors responsible for life conditions on the globe (Ellenberg 1988; Odum and Barrett 2005). Consequently, climatic factors are predominantly accountable for changes in the extent of ranges of both plant and animal species (Sykes et al. 1996; Box et al. 1999; Bakkenes et al. 2002; Walther et al. 2002; Fosaa et al. 2004; Thomas et al. 2004; Svenning and Skov 2006; Newson et al. 2009). Global warming observed in the recent decades has a significant impact on changes in the life activity of organisms, due, in particular, to lengthening of the growing season (Menzel et al. 2006; Feehan et al. 2009). The latter has been reported in numerous works as the main cause underlying shifts of tree species ranges as well as changes in the distribution of herbaceous plants and biodiversity (Neilson et al. 1992; Sykes and Prentice 1996; Solomon 1997; di Castri et al. 1988; Parmesan and Yohe 2003; Koca et al. 2006; Svenning and Skov 2006; Feehan et al. 2009; Dullinger et al. 2012; Bernhardt-Romermann et al. 2015; Helm et al. 2017). The evidence accumulated at the turn of the 20th and 21st centuries indicates that climate changes result not only in entire plant formations (biomes) shifting up to several hundred kilometres but also in changes in biomes physiognomy due to the inevitable fluctuations in species composition (Neilson et al. 1992). It is the ecotone vegetation that is particularly sensitive to climate change (di Castri et al. 1988).

Changes in the natural environment because of human activities are another important factor affecting the dispersion of organisms (Daehler and Carino 2000; Cronk and Fuller 2001; Tokarska-Guzik 2005). Considering the origin of dispersing organisms, they may be divided into two groups: invasive and expansive (Richardson et al. 2000). Invasive are those alien species that, after trespassing their natural range limits, first take over the anthropogenic habitats and then colonise the natural ones. Invasive species constitute a very important factor affecting biodiversity (Thomas 1998; Genovesi and Shine 2004; Thuiller et al. 2008; Jones et al. 2010). Expansive organisms, on the other hand, exploit the new environments within the limits of their natural range. This process is typical of native species having high dispersive potential.

We studied the distribution of Hedera helix in the forests of Central Poland during the years 2015-2017, examining an area of more than 250,000 ha, and compared the results with the accessible historical data. The aim of this paper is: 1) to discuss the expansion of ivy within the area of Central Poland shedding light on underlying causes and trends of dispersal and 2) illustrate the impact of climate change on increased fruiting intensity of the vine in Central Poland.

\section{Material AND Methods}

Ivy is native to the Mediterranean and Atlantic regions, while its northern and eastern limits in Europe run through southern Scandinavia, the Baltic countries, Belarus, Ukraine, and the Balkans. An important factor limiting the occurrence of ivy is the winter air temperature. The species does not reproduce sexually on areas subject to the impact of continental climates (Navasaitis 1995). The vine may grow in both open and shady places (Metcalfe 2005), but under natural conditions, it grows best in fresh, fertile soils in semi-shaded areas (Ellenberg 1988; Nawrocki 2010). H. helix tolerates low temperatures and drought (Laskurain et al. 2004). Owing to its clear range limits (both altitudinal and northeastern) and structural features that vary with climate oceanity, ivy has long been considered a species particularly suited to monitoring the shift of forest line because of climate change (Klötzli and Walther 1999). The eastern part of Poland lies at the European eastern border of $H$. helix range. The density of ivy's natural locations within the country decreases from west to east and northeast (Boratyńska 1987; Zając and Zając 2001).

Our study was conducted in forest habitats supporting $H$. helix. The average forest area (percentage of land area) in Central Poland varies from a very low, around $5 \%$, in the north, to above $25 \%$ in the south. The overall biodiversity of the region was documented for more than half a century by, among others, Mowszowicz (1978) and Jakubowska-Gabara et al. (2011). Historical observations on ivy were provided by earlier works containing data concerning the occurrence of $H$. helix in 1970s and 1980s of the 20th century (Olaczek 1979; Jakubowska-Gabara 1988 and others). The source of the newest data on ivy distribution was both our own survey conducted in the years 2014-2018 and the most recent forest appraisal reports made by the State Forest Directorate of Łódź. In the article, we focused on the 
numbers of fruiting specimens only. The term 'fruiting specimen' was understood as an ivy specimen climbing support (a tree) and bearing fruits or flowers. Every easily identifiable group of ivy specimens was treated as a stand. The historical data by Olaczek (1974) were used to determine the increase in the number of $H$. helix fruiting and flowering specimens in 16 stands, where the species was first noted more than 40 years ago (Tab. 1). The structure of distribution of values denoting the occurrence of fruiting specimens in two time periods was assessed using Pearson's chi-squared test.

The occurrence of H. helix in forest habitats was determined using the ecological grid of forest site types (Forest Management Manual 2011). Forest habitats vary in terms of fertility and soil humidity gradients. Four levels of site fertility were distinguished, including coniferous forests (Coni.), mixed coniferous forests (Mix. coni.), mixed deciduous forests (Mix. deci.) and deciduous forests (Deci.). Within these units, four moisture levels were taken into account: dry, fresh, moist and swampy. Oligotrophic sites of dry and fresh coniferous forest correspond to the habitats of associations from the alliance Dicrano-Pinion, including Leucobryo-Pinetum, Peucedano-Pinetum and Querco roboris-Pinetum (European Environment Agency typology: nemoral Scots pine forests) (EEA 2007). More fertile sites of mixed and moist coniferous forests are represented by the associations: Querco roboris-Pinetum and Querco roboris-Pinetum molinietosum (EEA typology: mixed Scots pine-pedunculate oak forest). Mixed deciduous forests or mesotrophic habitats with a distinctly more fertile soils (EEA typology: mesophytic deciduous forests) are taken by poorer associations of the pedunculate oak-hornbeam forests: associations Tilio cordataeCarpinetum betuli and Galio sylvatici-Carpinetum betuli from the alliance Carpinion betuli. These also include the habitats of Luzulo pilosae-Fagetum from the alliance Fagion sylvaticae (EEA typology: atlantic and subatlantic lowland beech forest). Moist mixed deciduous forests are usually a disturbed communities Fraxino-Alnetum from the alliance Alno-Ulmion, or swampy alder woods Ribeso nigri-Alnetum from the alliance Alnion glutinosae. Acidophilus oak forest communities from the alliance Quercion robori-petraeae occupy mixed coniferous sites bordering the mixed deciduous sites. Deciduous forests take fertile and very fertile habitats with weakly acidic or neutral soils and are classified as either fresh deciduous forests, represented by typical communities of Tilio cordatae-Carpinetum betuli and Galio sylvatici-Carpinetum betuli, or moist deciduous forests, for example, association TilioCarpinetum stachyetosum sylvaticae. Swamp deciduous forests correspond to habitats taken by the ash-alder communities of Fraxino-Alnetum and, less frequently, by Carici remotae-Fraxinetum from the alliance AlnoUlmion as well as by Ribeso nigri-Alnetum from the alliance Alnion glutinosae (EEA typology - riverine and non-riverine swamp forests). The locations of ivy in the area under study were registered in the above grid of forest habitats (Fig. 3).

Climate change in Central Poland for the study years 1971-2010 was assessed based on the analyses of two data sources: the E-OBS gridded data set for daily temperatures (EU-FP6) and the data archives of the National Oceanic and Atmospheric Administration (NOAA) for temperatures and precipitation. The E-OBS data set, established under the project ENSEMBLES (EU-FP6; Haylock et al., 2008), has currently been updated under the European Climate Assessment \& Dataset (EC\&D), and data were gridded across a regular rectangular grid of a resolution of $0.25^{\circ}$ (ca. $25 \mathrm{~km}$ in Poland). The E-OBS data were taken from the set 17.0 version of April 2018. In addition, analyses of changes in the average daily air temperatures and precipitation sums were made for several meteorological stations located in Central Poland, based on the NOAA data. The data were averaged for four seasons in successive decades and plotted on the graphs. The following tools were used to analyse and visualise the results: the Ferret software: Data Visualization and Analysis (Ferret Software), Climate Data Operators (CDO) and the R Project for Statistical Computing (R system).

\section{Results}

\section{Climate change}

Analyses of meteorological data indicate that Central Poland witnessed a significant climate change for the past four decades. From maps in Figure 1, illustrating the spatial distribution of temperatures for the years 1971-2010, it follows that there was a clear increase in the daily air temperature in Central Poland in successive decades. The most pronounced impact of climate 

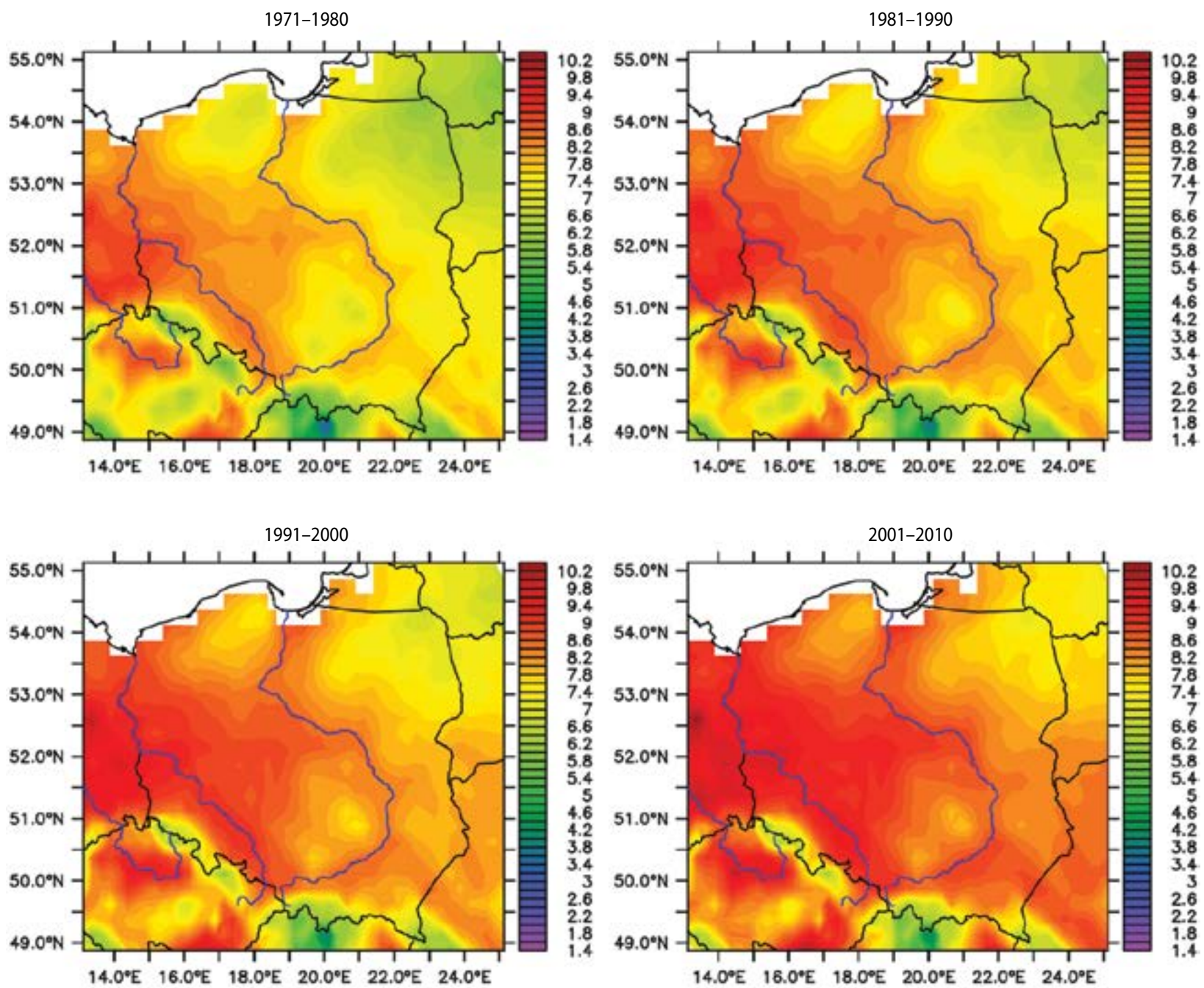

Figure 1. Increase in average air temperature $\left({ }^{\circ} \mathrm{C}\right)$ in Poland in successive decades for the years $1971-2010$, based on the E-OBS data

warming was observed in mid-Poland and in southwestern parts of the region.

The graphs presented in Figure 2 (DJF, MAM, JJA, $\mathrm{SON}$ ) illustrate changes in the average air temperatures and precipitation at selected meteorological stations in Central Poland for the period 1981-2010. Each point on the graphs represents sums of daily mean air temperature and of precipitation for a given station, averaged for four seasons and three successive decades. The graphs provide clear evidence of climate warming and the increase in the precipitation amounts at the stations. This is particularly significant for the summer months' temperatures (JJA), which is marked with an arrow on the graph.

\section{SURVEY OF IVY OCCURRENCE}

Altogether 474 natural sites of $H$. helix were recorded in the forests of Central Poland. Ivy was encountered in forests having a natural character and in the intensively managed forest stands. In dense stands, ivy was usually creeping on the ground, and climbing individuals were encountered only in the canopy gaps. However, in loose stands, where there was a sufficient sunlight, the vine was found to be readily climbing and producing fruits even under the tree canopy. Flowering ivy was recorded at 121 sites, where total of 1,416 specimens of $H$. helix were registered. Naturally occurring specimens of $H$. helix were recorded in nine forest habitat types (Fig. 3). 

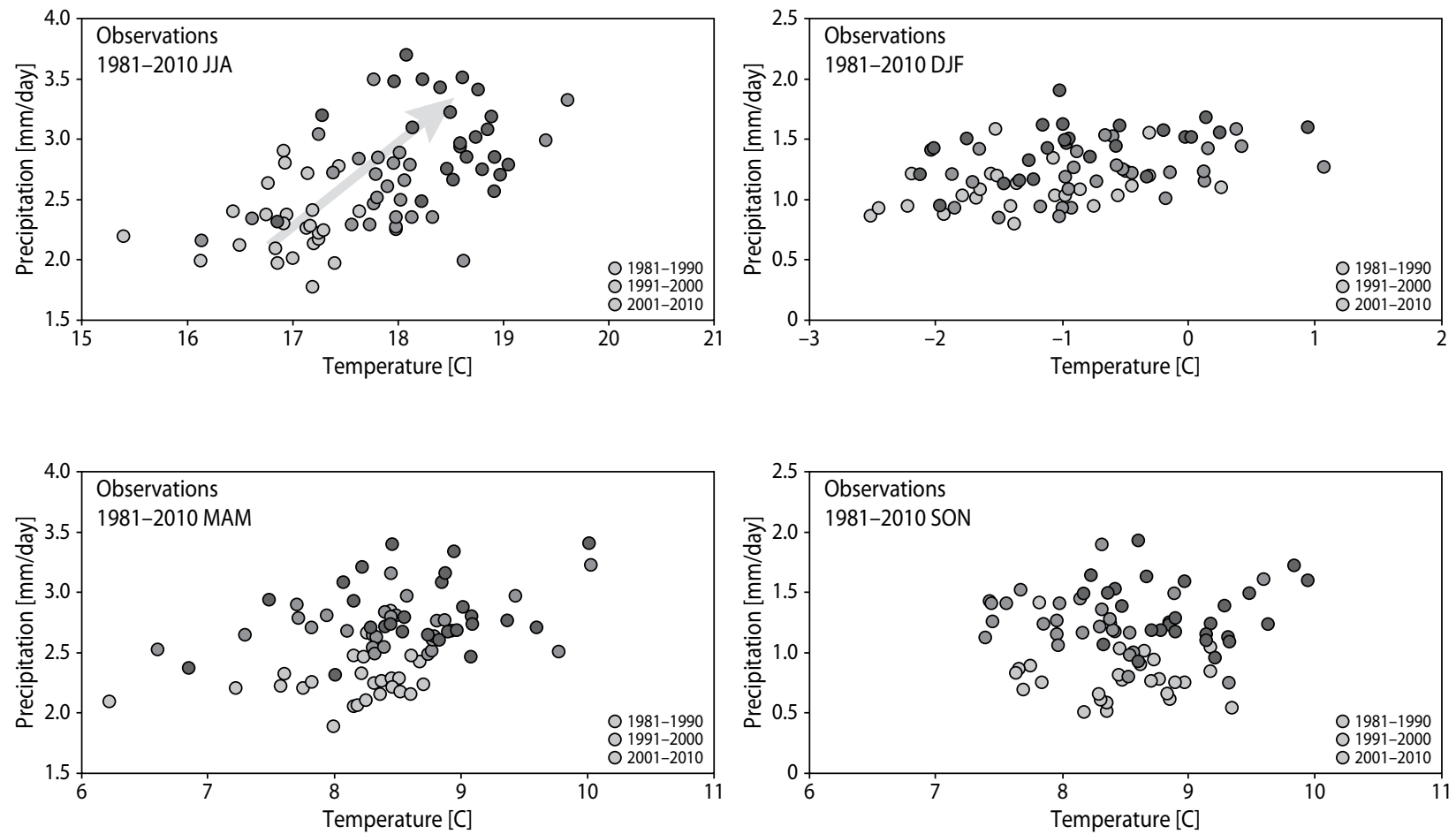

Figure 2. Average seasonal air temperature $\left({ }^{\circ} \mathrm{C}\right)$ and precipitation $(\mathrm{mm} /$ day $)$ in Poland at meteorological stations pictured in Fig. 1, each point illustrating temperature and precipitation at individual station, averaged for three decades: 1981-1990 (green), 1991-2000 (blue) and 2001-2010 (red). Data were taken from the NOAA database. Abbreviations denote months of individual seasons: DJF, winter; MAM, spring; JJA, summer; and SON, autumn

The species was most frequently found in fresh deciduous forest sites (at more than half of the sites examined - about 53\%), whilst only sporadically in fresh coniferous sites. Considerably less stands of ivy (around $38 \%$ ) were recorded in moist habitats. The vine was rarely found in habitats of fertile swamp forests (about $10 \%$ ) and not found at all in dry coniferous forest sites.

The flowering ivy was mainly encountered as a component of fringe communities at forest edges, along roadsides and railway lines cutting across forest tracts. Nearly one-fourth of $H$. helix sites were recorded in the forest interior, in loose stands with a scarce shrub layer. In dense forests, ivy was mostly found climbing trees growing at the peripheries of tree stand gaps (Fig. 4).

The comparison of findings of ivy fruiting specimens in two time periods at selected sites and the results of the Pearson chi-squared test are given in Table 1.

From the results presented in Table 1B, it follows that there was a substantial increase in the numbers of fruiting specimens of ivy at most of the stands examined.

\section{Discussion}

The distribution of $H$. helix in Poland varied greatly over 10,000 years of the post-glacial history. This is well documented based on the results of palynological analyses of vegetation occurring during postglacial succession in Central Poland (Ralska-Jasiewiczowa et al. 2004; Hannah 2010). The presence of ivy pollen in Poland was recorded for the first time in the post-glacial period at the turn of Preboreal and Boreal periods (approximately 9,000 years ${ }^{14} \mathrm{C}$ before present) in the eastern part of the South Pomeranian Lakeland (Granoszewski et al. 2004). A wider distribution of ivy was noted in the climatic optimum of the Holocene, which fell in the Atlantic period $\left(8,000-5,000\right.$ years $\left.{ }^{14} \mathrm{C} \mathrm{BP}\right)$. In that period, the range of $H$. helix embraced the whole area 


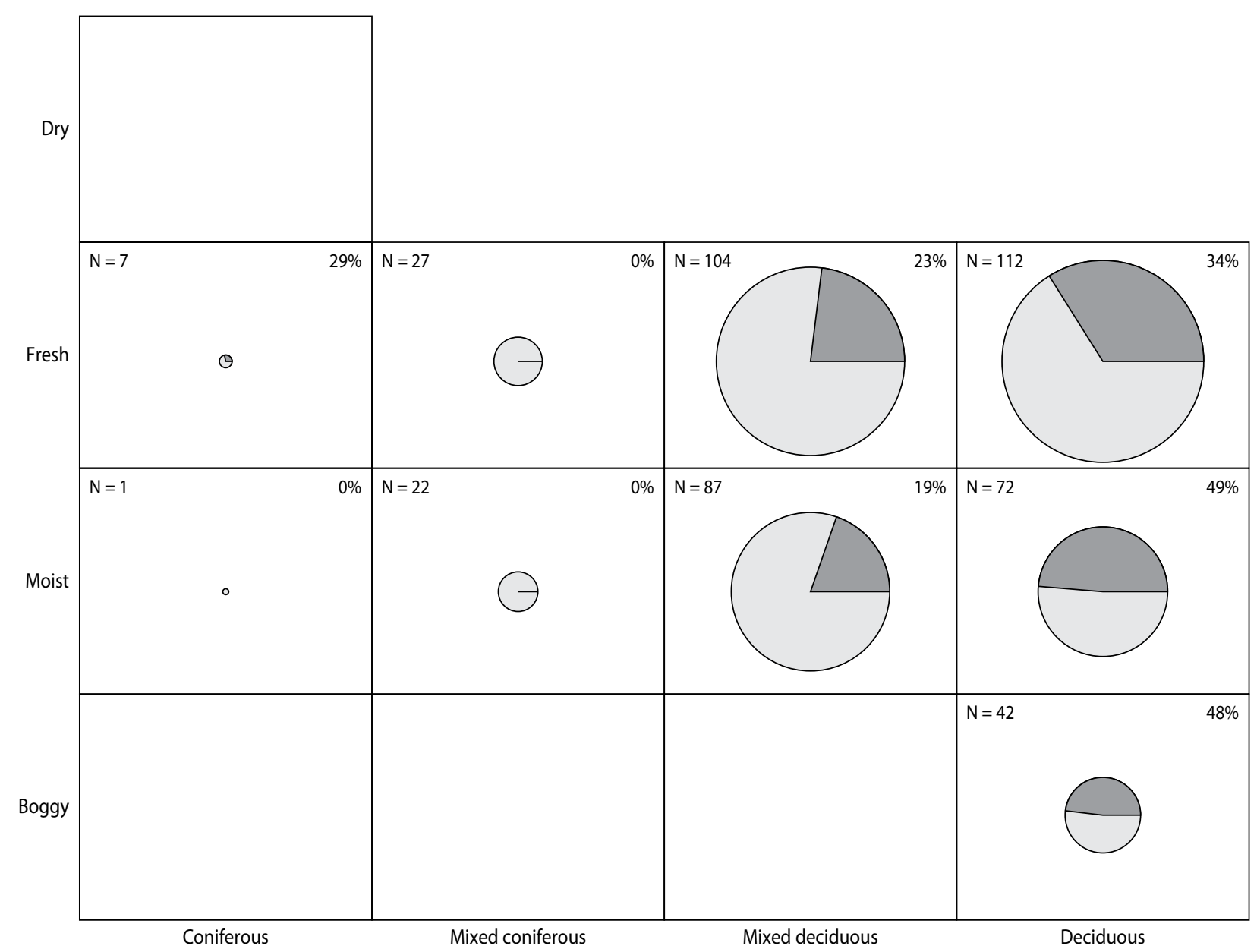

Figure 3. Occurrence of generative/vegetative specimens of $H$. helix in various forest site types: black, generative; white, vegetative

of today's Poland, including its central part, except of its most eastern portions. In the north-central Europe, the average annual temperatures were then higher by $2-3^{\circ} \mathrm{C}$, as compared to the present ones, and climate was more humid than today (Berner and Streif 2004). As is evidenced by various studies, the primeval forests of that time had canopy openings because natural mortality of oldest trees, which allowed for the gradual forest renewal (e.g. Rugani et al. 2013). The presence of numerous overexposed gaps could have been a factor conducive to the expansion of ivy under conditions of the favourable light and thermal regimes. About 4,000 years ${ }^{14} \mathrm{C} \mathrm{BP}$, the vine range clearly receded to the west, since at the end of the sub-Boreal period (3,000-2,500 years, $\left.{ }^{14} \mathrm{C} \mathrm{BP}\right)$ no more sites with pollen of ivy were found (Granoszewski et al. 2004). Moreover, no pollen grains of Hedera were detected in sediments from the sub-Atlantic period $\left(2500-0{ }^{14} \mathrm{C} \mathrm{BP}\right)$ collected in Poland (Milecka 2005). This indicates that the generative propagation of the vine was very limited at that period.

There is a large body of evidence to suggest that significant changes in Poland's climate have occurred since the mid-20th century (Kożuchowski 2004; Przybylak 2011). The past 40 years has been the warmest period in the history of instrumental observations in Poland (Klimada 2013). The average daily air temperatures have been increasing and, in particular, a slow process of 'warming up' of the winter period was observed (Kożuchowski and Żmudzka 2001). The above warming up, including the rise of the average annual temperatures, and especially those of autumn and win- 


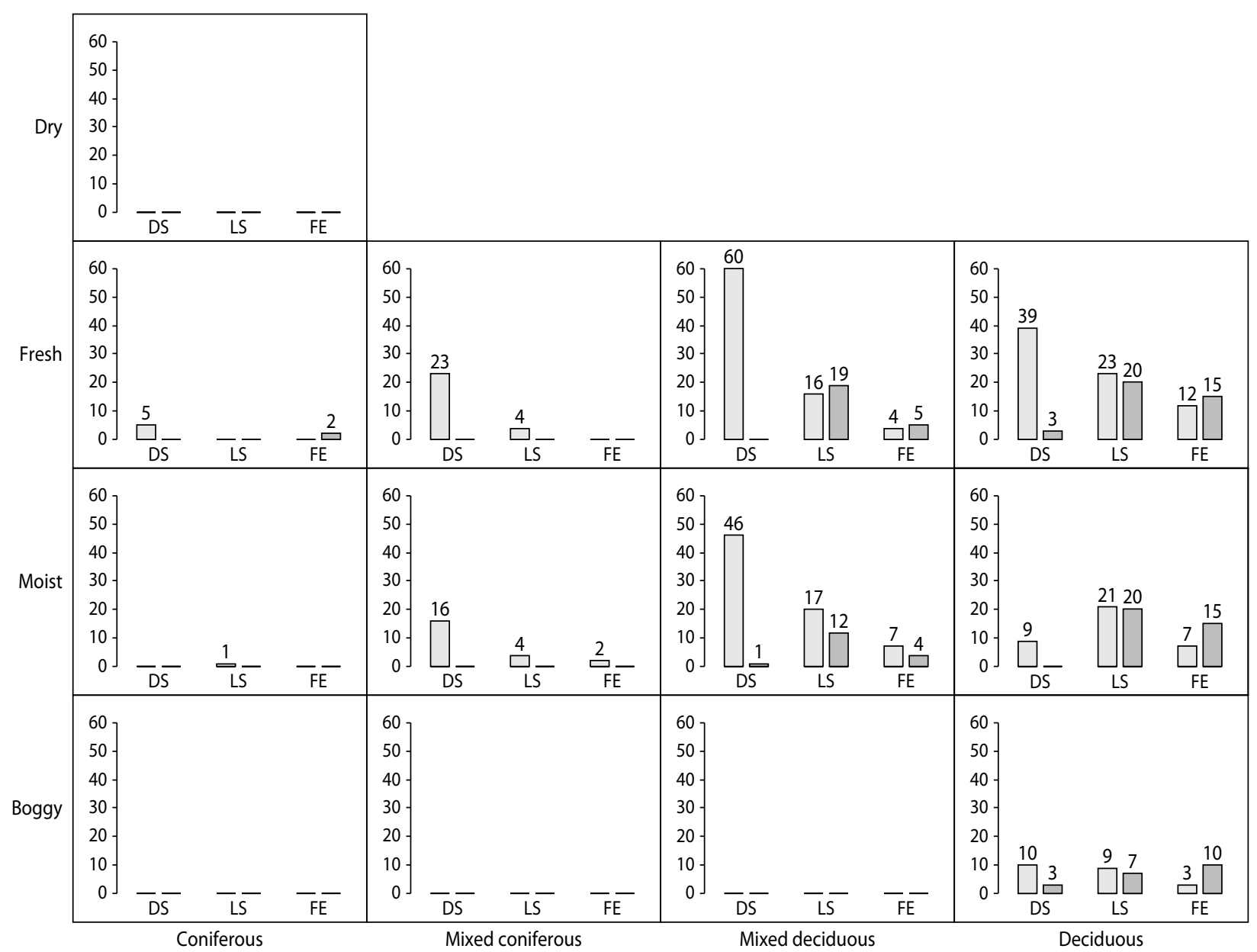

Figure 4. Number of flowering ivy specimens in dense stands (DS), in loose stands (LS) and at the forest edge (FE): black, generative; white, vegetative

ter months, bears some resemblance to the conditions of the Atlantic climatic optimum period, which favoured the then spread of $H$. helix to the east.

By the mid-20th century, the generatively reproducing $H$. helix was a rare component of the Polish forests, and the species was subject to legal protection until 2014 (Kucharski 2014). From the 1960s to the 1980s, the evidence started to accumulate on the increased presence of ivy in natural locations, with an enhanced occurrence of generatively reproducing individuals. The number of sites with flowering and fruiting specimens was increased by more than $450 \%$ during that time (Browicz and Gostyńska-Jakuszewska 1969). Most of the stands with flowering ivy were located in the western, southern and central parts of the country. No ivy specimens with flowers were then recorded in north- eastern Poland (Browicz and Gostyńska-Jakuszewska 1969; Boratyńska 1987). Only at the turn of the 20th and 21 st centuries, 36 sites of common ivy were found in the central-eastern part of the country, including three of them with flowers and fruits and seven with vines climbing the trees (Ciosek 2000). The inventory of ivy occurrence in Central Poland, at the end of 1970 of the last century, provided evidence of 147 flowering specimens growing on 24 sites (Olaczek 1979), whilst our studies in 2015-2017 indicated 1416 flowering and fruiting individuals on 121 sites. Consequently, there was a fivefold increase in the number of locations with flowering and fruiting specimens of $H$. helix in Central Poland for the past 40 years.

The vast majority of flowering and fruiting specimens of $H$. helix in Central Poland are encountered in 
Table 1.

A. Fruiting specimens of Hedera helix at natural stands in Central Poland in two time periods

\begin{tabular}{|c|l|c|c|}
\hline \multirow{2}{*}{ No. } & \multicolumn{2}{|c|}{ Stand } & \multicolumn{2}{c|}{$\begin{array}{c}\text { Number of fruiting } \\
\text { specimens of ivy }\end{array}$} \\
\cline { 3 - 4 } & & $1974^{*}$ & $2014-2018$ \\
\hline 1 & Głowno & 1 & 33 \\
\hline 2 & Szczawin & 1 & 4 \\
\hline 3 & Gostków & 1 & 9 \\
\hline 4 & $\begin{array}{l}\text { Reserve Polesie } \\
\text { Konstantynowskie }\end{array}$ & 10 & 247 \\
\hline 5 & Zofiówka & 1 & 4 \\
\hline 6 & Rydzyny & 2 & 9 \\
\hline 7 & Wojsławice & 12 & 47 \\
\hline 8 & Pyszków & 11 & 21 \\
\hline 9 & Złoczew & 22 & 55 \\
\hline 10 & Szustry & 46 & 125 \\
\hline 11 & Reserve Ryś & 3 & 3 \\
\hline 12 & Lasek Kurowski & 2 & 9 \\
\hline 13 & Siemkowice & 13 & 19 \\
\hline 14 & Wistka & 2 & 31 \\
\hline 15 & Wielopole & 1 & 4 \\
\hline 16 & Łódź Ruda & 2 & 102 \\
\hline
\end{tabular}

* Data by Olaczek 1974.
B. Results of the Pearson chi-squared test

\begin{tabular}{|c|c|c|c|c|c|}
\hline No. & $\mathrm{N}_{1}$ & $\mathrm{~N}_{2}$ & $\chi^{2}$ & $\mathrm{p}$ & $\mathrm{p}_{\text {(B.-H. })}$ \\
\hline 1 & 1 & 33 & 30.12 & $<0.000001$ & $<0.000001$ \\
\hline 2 & 1 & 4 & - & & \\
\hline 3 & 1 & 9 & 6.4 & 0.0114 & 0.0171 \\
\hline 4 & 10 & 247 & 218.56 & $<0.000001$ & $<0.000001$ \\
\hline 5 & 1 & 4 & - & & \\
\hline 6 & 2 & 9 & 4.45 & 0.0349 & 0.04188 \\
\hline 7 & 12 & 47 & 20.76 & $<0.000001$ & $<0.000001$ \\
\hline 8 & 11 & 21 & 3.12 & 0.077 & 0.084 \\
\hline 9 & 22 & 55 & 14.14 & 0.00017 & 0.000291 \\
\hline 10 & 46 & 125 & 36.5 & $<0.000001$ & $<0.000001$ \\
\hline 11 & 3 & 3 & - & & \\
\hline 12 & 2 & 9 & 4.45 & 0.0349 & 0.04188 \\
\hline 13 & 13 & 19 & 1.13 & 0.29 & 0.29 \\
\hline 14 & 2 & 31 & 25.48 & $<0.000001$ & $<0.000001$ \\
\hline 15 & 1 & 4 & - & & \\
\hline 16 & 2 & 102 & 96.15 & $<0.000001$ & $<0.000001$ \\
\hline Total & 130 & 722 & 411.34 & $<0.000001$ & \\
\hline
\end{tabular}

disturbed forest communities or on the forest edges. In dense stands, ivy shows the capacity to reproduce generatively only in the canopy openings. Generally, fragmentation of habitats is conducive to changes in species distribution, what was confirmed by the results of study on the increased share of vines in disturbed forest communities (Travis 2003; Londré and Schnitzer 2006).

At the same time, no evidence was found that the increased incidence of natural sites and flowering specimens of $H$. helix might be linked to changes in the ivy habitat preferences. The first extensive study on ivy distribution in Central Poland showed that most of its flowering specimens in natural locations were encountered in the oak-hornbeam or the alder-ash carr (Olaczek 1979) and this is still valid. Thus, the key driver behind the spread of the species beyond its eastern limit is climate 'warming up'. Another important factor that favours the ivy range shifts is the increased fragmentation of forest tracts.

\section{Conclusions}

1. Since the mid-20th century, $H$. helix, a rare species in the forests of Central Poland, with a weak capacity for generative reproduction, has become an expansive plant with increasing number of locations with flowering and fruiting individuals. The number of natural sites with generatively reproducing specimens increased, as much as fivefold in some cases.

2. The impulse for changes in the life strategy of H. helix is the increase in the average air temperatures, precipitation and solar radiation intensity, which has been observed for the past several decades.

3. The shift of the ivy range is favoured by the fragmentation of forest tracts, the increase in the proportion of forest edge zones and the loosening of tree canopy, in particular, in the old no longer economically managed stands. 
4. Habitat preferences of ivy at its eastern limit have not been changed, according to other studies. The species is found mainly in fresh and moderately wet habitats in the oak-hornbeam or alder-ash forest.

\section{ACKNOWLeDGements}

The authors wish to thank the foresters from the Lodz Regional Forest Directorate for their assistance in ivy localisation in the forest. The authors wish to thankfully acknowledge the assistance of the EU-FP6 project ENSEMBLES (http://ensembles-eu.metoffice.com) and the data providers in the ECA\&D project (http://www.ecad. eu) for providing the E-OBS data set, as well as that of the Ferret programme for analysis and graphics in this article. Ferret is a product of Pacific Marine Environmental Laboratory of the NOAA (information is available at http://ferret.pmel.noaa.gov/Ferret/).

\section{References}

Bakkenes, M., Alkemade, J.RM., Ihle, F., Leemans, R., Latour, J.B. 2002. Assessing effects of forecasted climate change on the diversity and distribution of European higher plants for 2050. Global Change Biology, 8, 390-407. DOI:10.1046/j.13541013.2001.00467.x

Berner, U., Streif, H.J. 2004. Klimafakten: der Rückblick - ein Schlüssel für die Zukunft., 4 Auflage. Schweizerbart'sche Verlagsbuchthandlung, Stuttgart, Germany.

Bernhardt-Romermann, M., et al. 2015. Drivers of temporal changes in temperate forest plant diversity vary across spatial scales. Global Change Biology, 21, 3726-3737. DOI: $11.1111 / \mathrm{gcb} .12993$

Boratyńska, K. 1987. Kwitnące i owocujące okazy Hedera helix L. w Polsce. Arboretum Kórnickie, 32, 19-36.

Box, E.O., Crumpacker, D.W., Hardin, E.D. 1999. Predicted effects of climatic change on distribution of ecologically important native tree and shrub species in Florida. Climatic Change, 41, 213-248. DOI:10.1023/A:1005483507351

Browicz, K., Gostyńska-Jakuszewska, M. 1969. Atlas rozmieszczenia drzew i krzewów w Polsce. PWN, Poznań, Poland, 29-32.
CDO Climate Data Operators Website: https://code. mpimet. mpg. de /projects/cdo/ [accessed 13 November 2017].

Ciosek, M.T. 2000. Bluszcz pospolity (Hedera helix L.) w środkowowschodniej Polsce. Rocznik Dendrologiczny, 48, 93-99.

Cronk, Q.C.B., Fuller, J.L. 2001. Plant invaders: the threat to natural ecosystems. Earthscan Publications Ltd., London and Sterling, UK.

Daehler, C.C., Carino, D.A. 2000. Predicting invasive plants: prospectus for a general screening system based on current regional models. Biological Invasions, 2, 93-103.

di Castri, F., Hansen, A.J., Holland, M.M. 1988. A new look at ecotones. Emerging International Projects on Landscape Boundaries. IUBS, UNESCO MAB, SCOPE, Biology International, Special Issue 17. The International Union of Biological Sciences News Magazine. Website: http://www.iubs.org/fileadmin/ user_upload/Biology-International/BI-Specials/ SPECIAL_ISSUE_17a.pdf [accessed 26 February, 2018].

Dullinger, S., et al. 2012. Extinction debt of highmountain plants under twenty-first-century climate change. Nature Climate Change, 2, 619-622. DOI:10.1038/nclimate1514

ECA\&D European Climate Assessment and Dataset, Website: https://www.eea.europa. eu/themes/climate/links/physical-science-on-climate/europeanclimate-assessment, http://www.ecad.eu [accessed: 5 April, 2018].

EEA, 2007. European forest types. Categories and types for sustainable forest management reporting and policy. EEA, Copenhagen. file://C:/Users/User/Downloads/eea_technical_report_9_2006\% 20(2).pdf

Ellenberg, H. 1988. Vegetation ecology of Central Europe. Cambridge University Press, Cambridge, UK.

EU-FP6 ENSEMBLES Website: http://ensembles-eu. metoffice.com [accessed 21 April, 2018].

Feehan, J., Harley, M., van Minnen, J. 2009. Climate change in Europe. 1. Impact on terrestrial ecosystems and biodiversity. A review. Agronomy for Sustainable Development, 29, 409-421. DOI:10.1051/ agro:2008066

Ferret Software Website: http://www.ferret. noaa.gov/ Ferret/ [accessed 25 April, 2018].

Forest Management Guide. 2011. Guide for identifying and mapping forest site types and plant communi- 
ties in the State Forests. Part II. Attachment, Ordinance No 55 of the Director General of the State Forests as of November 21, 2011. The State Forests Information Centre. Website: www.lasy.gov.pl [accessed 20 April 2018].

Fosaa, A.M., Sykes, M.T., Lawesson, J.E., Gaard, M. 2004. Potential effects of climate change on plant species in the Faroe Islands. Global Ecology and Biogeography, 13, 427-437. DOI:10.1111/j.1466822X.2004.00113.X

Genovesi, P., Shine, C. 2004. European strategy on invasive alien species. Nature and Environment 137. Council of Europe Publishing. Website: http://www. coe.int/t/dg4/cultureheritage/conventions/Bern/TPVS/sc24_inf01_en.pdf [accessed 15 April 2018].

Granoszewski, W., Krupiński, K.M., Nita, M., Nalepka, D. 2004. Hedera helix L. - Ivy. In: Late Glacial and Holocene history of vegetation in Poland based on isopollen maps (eds.: M. Ralska-Jasiewiczowa, M. Latałowa, K. Wasylikowa, K. Tobolski, E. Madeyska, H.E. Wright Jr, Ch. Turner). W. Szafer Institute of Botany, Polish Academy of Sciences, Kraków, 111-117.

Hannah, L. 2010. A global conservation system for climate-change adaptation. Conservation Biology, 24, 70-77.

Helm, N., Essl, F., Mirtl, M., Dirnböck, T. 2017. Multiple environmental changes drive forest floor vegetation in a temperate mountain forest. Ecology and Evolution, 7, 2155-2168. DOI: 10.1002/ece3.2801

Haylock, M.R., etal. 2008. A European daily high-resolution gridded dataset of surface temperature and precipitation. Journal Geophysical Research (Atmospheres), 113, D20119. DOI:10.1029/2008JD010201.

Jakubowska-Gabara, J. 1988. A new locality of the blossoming ivy, Hedera helix, in Central Poland. Chrońmy Przyrodę Ojczysta, 4 (2), 74-77.

Jakubowska-Gabara, et al. 2011. Atlas rozmieszczenia roślin naczyniowych w Polsce Środkowej. Gatunki chronione, rzadkie, ginące i narażone. Wydawnictwo Uniwersytetu Łódzkiego, Łódź.

Jones, C.C., Acker, S.A., Halpern, C.B. 2010. Combining local- and large-scale models to predict the distributions of invasive plant species. Ecological Applications, 20 (2), 311-326. DOI:10.1890/08-2261.1

Klimada. 2013. Website: http://klimada.mos.gov.pl/ zmiany-klimatu-w-polsce/tendencje-zmian-klimatu/ [accessed 25 February, 2018].
Klötzli, F., Walther, G.-R. 1999. Conference on recent shifts in vegetation boundaries of deciduous forests, especially due to general global warming. Proceedings of the Centro Stefano Franscini, Monte Verità, Springer, Basel AG.

Koca, D., Smith, B., Sykes, M.T. 2006. Modelling regional climate change effects on potential natural ecosystems in Sweden. Climatic Change, 78 (2/4), 381-406. DOI:10.1007/s10584-005-9030-1

Kożuchowski, K. 2004. The scale and tendencies of the contemporary changes in air temperature in Poland: Scale, conditions and perspectives of the contemporary climatic changes in Poland. Katedra Geografii Fizycznej i Zakład Dynamiki Środowiska i Bioklimatologii UŁ, Łódź, 25-45.

Kożuchowski, K., Żmudzka, E. 2001. The warming in Poland: the range and seasonality of the changes in air temperature in the second half of 20th century. Przeglad Geofizyczny, 1/2, 81-90.

Kucharski, L. 2014. Legal protection of plants in Poland in the years 1947-2011. Acta Botanica Silesiaca, 10, $5-16$.

Laskurain, N.A., Escudero, A., Olano, J.M., Loidi, J. 2004. Seedling dynamics of shrubs in a fully closed temperate forest: greater than expected. Ecography, 27, 650-658. DOI:10.1111/j.0906-7590.2004.03750.x

Londré, R.A., Schnitzer, S.A. 2006. The distribution of lianas and their change in abundance in temperate forests over the past 45 years. Ecology, 87 (12), 2973-2978. DOI:10.1890/00129658(2006)87[2973:TDOLAT]2.0.CO;2

Menzel, A., et al. 2006. European phenological response to climate change matches the warming pattern. Global Change Biology, 12, 1969-1976. DOI:10.1111/j.1365-2486.2006.01193.x

Metcalfe, D.J. 2005. Biological flora of the British Isles: Hedera helix L. Journal of Ecology, 93, 632-648. DOI:10.1111/j.1365-2745.2005.01021.x

Milecka, K. 2005. History of Lobelia lakes in Tuchola Pinewoods against the background of post-glacial forest development, Vol. 71, Geografia. Wydawnictwo Naukowe Uniwersytetu im. A. Mickiewicza, Poznań, Poland.

Mowszowicz, J. 1978. Conspectus florae Poloniae medianae (plantae vasculare) - Przegląd flory Polski Środkowej (rośliny naczyniowe). Uniwersytet Łódzki, Łódź. 
Navasaitis, M. 1995. Paprastosios gabenés (Hedera helix L.) biologijos Lietuvoje klausimu. Dendrologia Lithuaniae, 94, 9-12.

Nawrocki, T. 2010. English ivy Hedera helix L. Website: http://aknhp.uaa.alaska.edu; http://accs.uaa. alaska.edu/files/invasive-species/Hedera_helix_ BIO_HEHE.pdf [accessed 27 January, 2018].

Neilson, R.P., King, G.A., DeVelice, R.L., Lenihan, J.M. 1992. Regional and local vegetation patterns: the responses of vegetation diversity to subcontinental air masses. In: Landscape Boundaries: Consequences for Biotic Diversity and Ecological Flows (eds.: A.J. Hansen, F. di Castri). Springer-Verlag, New York, 129-149.

Newson, S.E., et al. 2009. Indicators of the impact of climate change on migratory species. Endangered Species Research, 7, 101-113. https://doi. org/10.3354/esr00162

NOAA Website: https://www.nodc.noaa.gov [accessed 15 March, 2017].

Odum, E.P., Barrett, G.W. 2005. Fundamentals of ecology Thomson Brooks/Cole, Belmont, California, USA.

Olaczek, R. 1979. Owocujący bluszcz pospolity Hedera helix w Polsce Środkowej. Chrońmy Przyrode Ojczysta, 35 (5), 5-17.

Parmesan, C., Yohe, G. 2003. A global coherent fingerprint of climate change impacts across natural systems. Nature, 421, 37-42.

Przybylak, R. 2011. Changes in Poland's over the last millennium. Czasopismo Geograficzne, 82 (1/2), 23-48.

R system - The R Project for Statistical Computing, Website: https://www.r-project.org/, [accessed 06 March, 2017].

Ralska-Jasiewiczowa, et al. 2004. Late Glacial and Holocene history of vegetation in Poland based on isopollen maps. Kraków, Poland: Institute of Botany, Polish Academy of Sciences.

Richardson, D.M., Pyšek, P., Rejmánek, M., Barbour, M.G., Panetta, F.D., West, C.J. 2000. Naturalization and invasion of alien plants: concepts and definitions. Diversity and Distribution, 6 (2), 93-107. DOI:10.1046/j.1472-4642.2000. 00083.x
Rugani, T., Diaci, J., Hladnik, D. 2013. Gap dynamics and structure of two old-growth beech forest remnants in Slovenia. PLoS One, 8 (1), e52641.

Solomon, A.M. 1997. Natural migration rates of trees: global terrestrial carbon cycle implications. In: Past and future rapid environmental changes. The spatial and evolutionary responses of terrestrial biota (eds.: B. Huntley, W. Cramer, A.V. Morgan, H.C. Prentice, J.R.M. Allen). Springer-Verlag, New York, UK, 455-468.

Svenning, J.-Ch., Skov, F. 2006. Potential impact of climate change on the northern nemoral forest herb flora of Europe. Biodiversity and Conservation, 15, 3341-3356.

Sykes, M.T., Prentice, I.C. 1996. Climate change, tree species distributions and forest dynamics: a case study in the mixed conifer/northern hardwoods zone of Northern Europe. Climatic Change, 34, 161-177.

Sykes, M.T., Prentice, I.C., Cramer, W. 1996. A bioclimatic model for the potential distributions of north European tree species under present and future climates. Journal of Biogeography, 23, 203-233.

Thomas, C.D., et al. 2004. Extinction risk from climate change. Nature, 427, 145-148.

Thomas, L.K. 1998. Topographic alterations, forest structure, and invasion by English Ivy (Hedera helix L.) in the Rock Creek Floodplain, Washington, D.C. Natural Areas Journal, 18 (2), 164-168.

Thuiller, W., et al. 2008. Predicting global change impacts on plant species' distributions: Future challenges. Perspectives Plant Ecology Evolution and Systematics, 9 (3/4), 137-152. DOI:10.1016/j.ppees.2007.09.004

Tokarska-Guzik, B. 2005. The establishment and spread of alien plant species (kenophytes) in the flora of Poland. Wydawnictwo Uniwersytetu Śląskiego, Katowice, Poland.

Travis, J.M.J. 2003. Climate change and habitat destruction: a deadly anthropogenic cocktail. Proceedings of the Royal Society London B, 270, 467-473.

Walther, G.-R., et al. 2002. Ecological responses to recent climate change. Nature, 416, 389-395.

Zając, A., Zając, M. 2001. Distribution atlas of vascular plants in Poland. Laboratory of Computer Chorology, Institute of Botany Jagiellonian University, Kraków, Poland. 